\title{
A chemically defined medium for slime production by coagulase-negative staphylococci
}

\author{
M. HUSSAIN, J. G. M. HASTINGS* and P. J. WHITE†
}

Departments of Molecular Biology and Biotechnology, and "Experimental and Clinical Microbiology, The University of Sheffield, Western Bank, Sheffield S10 2TN

\begin{abstract}
Summary. In a chemically defined medium in which the principal constituents were glucose, 18 amino acids, two purines and six vitamins, eight strains of coagulase-negative staphylococci grew as rapidly and heavily as in tryptic soy broth. Slime formation was slightly better in the defined medium than in tryptic soy broth.
\end{abstract}

\section{Introduction}

In recent years coagulase-negative staphylococci (CNS) have come to be recognised as a major cause of septicaemia in patients with implanted prosthetic devices and intravenous catheters. Some isolates produce extracellular slime which is thought to be important in the genesis of these plastic-associated infections. ${ }^{1-5}$ The slime substance is loosely bound to staphylococcal cells and can be washed off. ${ }^{6}$

In published methods of preparing staphylococcal slime, bacteria have been grown under fluid on complex media solidified with $\operatorname{agar}^{7-9}$ or in liquid culture, ${ }^{10}$ and, after separating the slime layer and removing bacteria by centrifugation, the supernatant liquid has been used as starting material for analyses. These slime preparations inevitably contain some ingredients of high molecular weight from the media. To avoid this problem, Peters et al. ${ }^{6}$ used an elaborate chemically defined medium formulated to meet the growth requirements of streptococci $;{ }^{11}$ it contained ingredients not usually required by staphylococci. The present study was designed to devise a simpler chemically defined medium that would support growth and maximal slime production by CNS.

\section{Materials and methods}

\section{Bacterial strains}

Eight strains of Staphylococcus epidermidis were used: reference strains RP-12 (ATCC 35983) and RP62A (ATCC 35984); clinical isolates C762, C1543, C1276 and A2057, all isolated in the Bacteriology Department, Royal Hallamshire Hospital, Sheffield from infected long intravenous catheters; and skin isolates C362 and C988. Strains RP-12, RP-62A, C762

Received 28 March 1990; accepted 31 July 1990.

* Present address: Department of Clinical Microbiology, The Queen Elizabeth Medical Centre, Birmingham B15 2TH.

† Correspondence should be sent to Dr P. J. White. and $\mathrm{C} 1543$ produced slime, as determined by the method of Christensen et al. ${ }^{3}$

\section{Growth requirements}

Amino acid requirements for growth were determined by growth tests with Gladstone's medium. ${ }^{12}$ Each amino acid was prepared as a concentrated stock solution so that the addition of $0.2 \mathrm{ml}$ of each gave the final concentration required in $10 \mathrm{ml}$ of the complete medium. Bacteria were grown overnight on nutrientagar slopes, washed twice in physiological saline and resuspended in saline to a concentration of $c .1 \times 10^{8}$ $\mathrm{cfu} / \mathrm{ml} ; 0 \cdot 1 \mathrm{ml}$ of this suspension was added to $10 \mathrm{ml}$ of medium in a $15 \times 1.7-\mathrm{cm}$ test tube and incubated with shaking at $37^{\circ} \mathrm{C}$. Growth was estimated by eye after incubation for 24 and $48 \mathrm{~h}$.

Carbohydrate requirements were determined with the same medium but replacing glucose by different sugars (galactose, mannose, fructose, sucrose, lactose and maltose), each $1 \% \mathrm{w} / \mathrm{v}$. The experimental procedures (inoculation, incubation and growth estimation) were as described for the determination of amino acid needs.

The effect of various supplements on slime production was investigated by adding them to vitamin-containing medium $\mathrm{A}^{13}-\mathrm{Na}_{2} \mathrm{HPO}_{4} \cdot 12 \mathrm{H}_{2} \mathrm{O}, 11.2 \mathrm{~g}$; $\mathrm{KH}_{2} \mathrm{PO}_{4}, 2 \cdot 4 \mathrm{~g} ;\left(\mathrm{NH}_{4}\right)_{2} \mathrm{SO}_{4}, 2 \mathrm{~g} ; \mathrm{MgSO}_{4} \cdot 7 \mathrm{H}_{2} \mathrm{O}$, $50 \mathrm{mg} ; \mathrm{MnCl}_{2} \cdot 4 \mathrm{H}_{2} \mathrm{O}, 4 \mathrm{mg} ; \mathrm{FeSO}_{4} \cdot 7 \mathrm{H}_{2} \mathrm{O}, 2.8 \mathrm{mg}$; glucose, $10 \mathrm{~g}$; biotin, $0.1 \mathrm{mg}$; nicotinic acid, $2 \mathrm{mg}$; D-pantothenic acid, Ca salt, $2 \mathrm{mg}$; pyridoxal, $4 \mathrm{mg}$; pyridoxamine dihydrochloride, $4 \mathrm{mg}$; riboflavin, $2 \mathrm{mg}$; thiamin hydrochloride, $2 \mathrm{mg}$; and water to $1 \mathrm{~L}$. Medium A plus vitamins was prepared by mixing four separately autoclaved solutions. Solution $A$ : $\mathrm{Na}_{2} \mathrm{HPO}_{4} \cdot 12 \mathrm{H}_{2} \mathrm{O}, \mathrm{KH}_{2} \mathrm{PO}_{4},\left(\mathrm{NH}_{4}\right)_{2} \mathrm{SO}_{4}$ at $\times 5$ final concentration; Solution $B$ : salts $\left(\mathrm{Mg}^{2+}, \mathrm{Mn}^{2+}\right.$ and $\mathrm{Fe}^{2+}$ ) dissolved together at $\times 50$ final concentration in $0.01 \mathrm{M}, \mathrm{H}_{2} \mathrm{SO}_{4}$; Solution $C$ : glucose $20 \% \mathrm{w} / \mathrm{v}$; Solution $D$ : a mixture of vitamins prepared at $\times 100$ final concentration. For $500 \mathrm{ml}$ of medium A, $100 \mathrm{ml}$ of solution A was autoclaved with $360 \mathrm{ml}$ of glass- 
distilled water and, after cooling, $10 \mathrm{ml}$ of solution $\mathrm{B}$, $25 \mathrm{ml}$ of solution $\mathrm{C}$ and $5 \mathrm{ml}$ of solution $\mathrm{D}$ were added.

The supplements were: 1 . $\mathrm{Na}$ acetate $3 \mathrm{H}_{2} \mathrm{O} 0 \cdot 5 \%$ w/v. 2. Trace elements (/L of medium), $5 \mathrm{ml}$ of stock solution containing $\mathrm{FeSO}_{4}(\mathrm{NH})_{2} \mathrm{SO}_{4} \cdot 6 \mathrm{H}_{2} \mathrm{O}, 116 \mathrm{mg}$; $\mathrm{HBO}_{3}, 232 \mathrm{mg} ; \mathrm{CoSO}_{4} \cdot 7 \mathrm{H}_{2} \mathrm{O}, 95 \cdot 6 \mathrm{mg} ; \mathrm{CuSO}_{4} \cdot 5 \mathrm{H}_{2} \mathrm{O}$, $8 \mathrm{mg} ; \mathrm{MnSO}_{4} \cdot 4 \mathrm{H}_{2} \mathrm{O}, 8 \mathrm{mg} ;\left(\mathrm{NH}_{4}\right)_{6} \mathrm{Mo}_{7} \mathrm{O}_{24} \cdot 4 \mathrm{H}_{2} \mathrm{O}$, $22 \mathrm{mg} ; \mathrm{ZnSO}_{4} \cdot 7 \mathrm{H}_{2} \mathrm{O}, 174 \mathrm{mg} ; 1 \mathrm{~N} \mathrm{H}_{2} \mathrm{SO}_{4}, 10 \mathrm{ml}$; water to $1 \mathrm{~L}$. 3. Casamino acids (Difco) $3 \% \mathrm{w} / \mathrm{v} .4$. Yeast extract (Oxoid) $0 \cdot 1 \%$ w/v. 5. Purines/pyrimidines, $20 \mathrm{mg}$ each of adenine, guanine and uracil / $\mathrm{L}$ of medium. 6. Defined amino acid mixture containing (mg/L): L-aspartic acid, 150; L-alanine, 100; Larginine, 100; L-cystine, 50; glycine, 100; L-glutamic acid, 150; L-histidine, 100; L-isoleucine, 150; L-lysine, 100 ; L-leucine, 150; L-methionine, 100; L-phenylalanine, 100; L-proline, 150; L-serine, 100; L-threonine, 150; L-tryptophan, 100; L-tyrosine, 100; L-valine, 150.

\section{Preparation of the chemically defined medium}

The ingredients of the medium were first made up separately in five groups (table I). The components of group 1 were dissolved in $700 \mathrm{ml}$ of water. Groups 3, 4 and 5 were made as concentrated solutions as follows: group 3, $\times 100$; group 4, $\times 20$ and group 5, $\times 100$. Except for group 2, the groups were mixed, made up to $900 \mathrm{ml}$ with glass-distilled water and autoclaved at $121^{\circ} \mathrm{C}$ for $15 \mathrm{~min}$. Group 2 ingredients (made up to $100 \mathrm{ml}$ in glass-distilled water) were autoclaved separately and added to the rest when cool. For brevity the defined medium is referred to as medium HHW (Hussain, Hastings, White).

\section{Detection of slime production}

Because there is at present no single generally

Table I. Composition of a new chemically-defined medium HHW for slime production by CNS

\begin{tabular}{|c|c|c|c|}
\hline Ingredients & $\mathrm{mg} / \mathrm{L}$ & Ingredients & $\mathbf{m g} / \mathbf{L}$ \\
\hline \multicolumn{2}{|l|}{ Group 1} & \multicolumn{2}{|l|}{ Group 2} \\
\hline $\mathrm{Na}_{2} \mathrm{HPO}_{4} \cdot 2 \mathrm{H}_{2} \mathrm{O}$ & 10000 & Glucose & 10000 \\
\hline $\mathrm{KH}_{2} \mathrm{PO}_{4}$ & 3000 & $\mathrm{MgSO}_{4} \cdot 7 \mathrm{H}_{2} \mathrm{O}$ & \multirow[t]{2}{*}{500} \\
\hline L-Aspartic acid & 150 & & \\
\hline L-Alanine & 100 & \multicolumn{2}{|l|}{ Group 3} \\
\hline L-Arginine & 100 & \multicolumn{2}{|l|}{ Biotin } \\
\hline L-Cystine & 50 & \multicolumn{2}{|l|}{ Nicotinic acid } \\
\hline Glycine & 100 & \multicolumn{2}{|l|}{ D-Pantothenic acid, $\mathrm{Ca}$ salt } \\
\hline L-Glutamic acid & 150 & \multicolumn{2}{|l|}{ Pyridoxal } \\
\hline L-Histidine & 100 & \multicolumn{2}{|l|}{ Pyridoxamine dihydrochloride 4} \\
\hline L-Isoleucine & 150 & \multicolumn{2}{|l|}{ Riboflavin } \\
\hline L-Lysine & 100 & \multirow{2}{*}{\multicolumn{2}{|c|}{ Thiamin hydrochoride }} \\
\hline L-Leucine & 150 & & \\
\hline L-Methionine & 100 & \multicolumn{2}{|l|}{ Group 4} \\
\hline L-Phenylalanine & 100 & Adenine sulphate & 20 \\
\hline L-Proline & 150 & \multirow{2}{*}{\multicolumn{2}{|c|}{ Guanine hydrochloride }} \\
\hline L-Serine & 100 & & \\
\hline L-Threonine & 150 & \multicolumn{2}{|l|}{ Group 5} \\
\hline L-Tryptophan & 100 & $\mathrm{CaCl}_{2} \cdot 6 \mathrm{H}_{2} \mathrm{O}$ & 10 \\
\hline L-Tyrosine & 100 & $\mathrm{MnSO}_{4}$ & 5 \\
\hline L-Valine & 150 & $\left(\mathrm{NH}_{4}\right)_{2} \mathrm{SO}_{4} \cdot \mathrm{FeSO}_{4} \cdot 6 \mathrm{H}_{2} \mathrm{O}$ & 6 \\
\hline (Final pH value $7 \cdot 2$ ) & & & \\
\hline
\end{tabular}

accepted method for determining slime production, three different methods were compared: a qualitative tube assay; a spectrophotometric method that assessed biofilm on the bottom of wells but not on their walls; and an ATP bioluminescence method that measured the biomass of all adherent bacteria, whether they were on the bottom of the wells or on their walls.

Tube method. ${ }^{3}$ The test medium $(10 \mathrm{ml})$ in a glass 28 -ml screw-capped bottle was inoculated with $0.1 \mathrm{ml}$ of a saline suspension of bacteria of $\operatorname{OD}_{540} 1.0$ and containing c. $1 \times 10^{9} \mathrm{cfu} / \mathrm{ml}$. After incubation for $18 \mathrm{~h}$ at $37^{\circ} \mathrm{C}$, the bottle contents were poured out and $10 \mathrm{ml}$ of an aqueous solution of alcian blue $0.1 \% \mathrm{w} / \mathrm{v}$ was added to stain adherent bacteria. A blue-stained film lining the bottle walls was taken to indicate slime production.

ATP bioluminescence assay. Cultures grown overnight in HHW medium or tryptic soy broth were diluted 1 in 100 with fresh medium to contain $c .1 \times 10^{7}$ $\mathrm{cfu} / \mathrm{ml}$ and $200-\mu \mathrm{l}$ volumes were poured (in triplicate) into flat-bottomed wells of a polystyrene microtitration plate (Amersham International plc, Buckinghamshire). The plate was covered and incubated at $37^{\circ} \mathrm{C}$ for $18 \mathrm{~h}$. The fluid in the wells was aspirated and the wells were washed twice with saline by means of an automated plate washer (Amersham International). ATP was extracted from adherent bacteria by adding $200 \mu \mathrm{l}$ of trichloroacetic acid $2 \cdot 5 \% \mathrm{w} / \mathrm{v}$. A $10-\mu \mathrm{l}$ sample of the extract was then transferred to a well of another microtitration plate containing $200 \mu$ l of Tris- $\mathrm{HCl}$ buffer (pH 7.8); $30 \mu \mathrm{l}$ of ATP monitoring reagent (LKB-Wallac Oy, Finland, 1243-102; one vial reconstituted with $10 \mathrm{ml}$ of distilled water) was added and light output was measured in a microtitration plate luminometer (Amerlite, Amersham International). A second reading was made after adding $10 \mu \mathrm{l}$ of ATP standard (LKB-Wallac Oy, Finland, 1243-201; one vial reconstituted with $10 \mathrm{ml}$ of distilled water). The light reading in $\mathrm{mV}$ was converted to picomoles of ATP according to the following formula: ATP(pmoles $)=[$ Light output $(\mathrm{mV})$ from sample/Light output $(\mathrm{mV})$ from standard] $\times$ Amount of standard added(picomoles).

Spectrophotometric method. The method of Christensen et al. ${ }^{14}$ was used with three replicates. Bacterial suspensions $(200 \mu \mathrm{l})$ in appropriate medium containing $c .1 \times 10^{7} \mathrm{cfu} / \mathrm{ml}$ were poured in triplicate into a polystyrene $96-w e l l$ flat-bottomed plate. After incubation for $18 \mathrm{~h}$ at $37^{\circ} \mathrm{C}$, fluid in the wells was aspirated and the wells were washed twice with saline. Adherent growth was stained with safranin $0.1 \%$ for $1 \mathrm{~min}$, washed with distilled water and allowed to dry. OD was determined at $490 \mathrm{~nm}$ with a Microelisa Minireader MR590 (Dynatech, Guernsey, Channel Islands).

\section{Measurement of growth}

Medium HHW and tryptic soy broth $(100 \mathrm{ml}$ of each in separate $250-\mathrm{ml}$ flasks) were each inoculated 
with $0.1 \mathrm{ml}$ of a 1 in 10 dilution of an overnight culture in the same medium and incubated with shaking at $37^{\circ} \mathrm{C}$ for $24 \mathrm{~h}$. Turbidity was measured in an EEL colorimeter (Evans Electroselenium Co. Ltd, Halstead, Essex); the zero was adjusted with uninoculated medium. Growth curves were made from viable counts on blood agar after growing the strains in these two media.

\section{Results}

\section{Measurement of growth}

Growth curves constructed from viable counts made with strain RP-62A growing in medium HHW and tryptic soy broth are shown in the figure. Growth was slow at first in the medium HHW, but after $18 \mathrm{~h}$ the numbers of viable bacteria (cfu) in both media were the same. Similar results were obtained with the other strains.

\section{Growth requirements}

All strains required valine and arginine for growth, as described by White and Woods. ${ }^{15}$ Leucine and isoleucine were required by all strains for growth by $18 \mathrm{~h}$; their absence delayed growth. One strain only did not require tyrosine and two only did not need threonine for growth in $18 \mathrm{~h}$. No strain required aspartic acid and two strains only required proline and histidine. However, if more than two of the amino acids in table II were omitted simultaneously, none of the strains grew. There were no clear differences in amino-acid requirements of slime-producing and slime

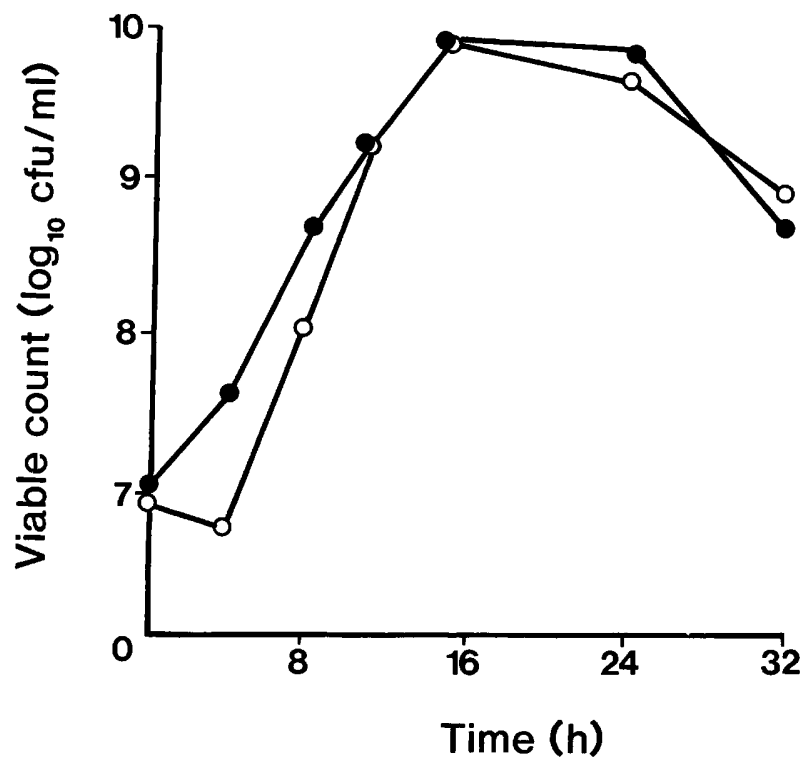

Figure. Growth of strain RP-62A in medium HHW $(\mathrm{O})$ and in tryptic soy broth (O) with shaking at $37^{\circ} \mathrm{C}$.

non-producing isolates; the two slime-producing reference strains, RP-62A and RP-12, had identical amino-acid requirements (table II).

Three slime-producing strains (RP-12, RP-62A and C762) and one slime non-producing strain (C988) grew well with all carbohydrate sources tested (table III). Strains C1543, A2057, C362 and C1276 grew well with glucose, but either grew poorly or not at all with most of the other sugars. There was no clear difference in the carbohydrate requirements of slime-producing and slime non-producing strains. Glucose was the only

Table II. Amino acid needs of eight strains of CNS

\begin{tabular}{|c|c|c|c|c|c|c|c|c|}
\hline \multirow{3}{*}{$\begin{array}{l}\text { Omission } \\
\text { from medium of } \\
\text { Gladstone }^{12}\end{array}$} & \multicolumn{8}{|c|}{ Growth of strains } \\
\hline & \multicolumn{4}{|c|}{ slime non-producers } & \multicolumn{4}{|c|}{ slime producers } \\
\hline & A2057 & C988 & $\mathrm{C} 362$ & $\mathrm{C} 1276$ & $\mathrm{C} 1543$ & $\mathrm{C} 762$ & RP-12 & RP-62A \\
\hline Alanine & g & $\mathbf{g}$ & d & d & - & $\mathbf{g}$ & $\mathbf{g}$ & g \\
\hline Arginine & - & - & - & - & - & - & - & - \\
\hline Aspartic acid & $\mathrm{g}$ & g & $\mathrm{g}$ & g & g & g & g & g \\
\hline Cysteine & g & $\mathrm{g}$ & - & - & d & - & - & - \\
\hline Glutamic acid & - & $\underline{-}$ & - & - & - & g & g & $\mathbf{g}$ \\
\hline Glycine & 8 & $\mathbf{g}$ & $\mathrm{g}$ & d & d & d & $\mathbf{g}$ & $\mathbf{g}$ \\
\hline Histidine & g & $\mathrm{g}$ & - & d & g & $\mathbf{g}$ & g & $\mathrm{g}$ \\
\hline Isoleucine & - & d & d & - & $\mathrm{d}$ & $=$ & - & d \\
\hline Leucine & - & - & - & _- & - & d & d & d \\
\hline Lysine & g & g & g & - & d & d & $\mathrm{g}$ & g \\
\hline Methionine & g & $\mathrm{g}$ & $\mathrm{g}$ & $\mathbf{g}$ & g & d & $\mathrm{g}$ & $\mathrm{g}$ \\
\hline Phenylalanine & g & $=$ & d & - & $\mathrm{g}$ & d & $\mathrm{g}$ & $\mathrm{g}$ \\
\hline Proline & $\mathbf{g}$ & - & $\mathbf{g}$ & $\mathbf{g}$ & g & - & g & g \\
\hline Serine & $\mathrm{g}$ & $\mathbf{g}$ & $\mathrm{g}$ & d & $\mathrm{d}$ & $\mathbf{g}$ & $\mathrm{g}$ & $\mathrm{g}$ \\
\hline Threonine & $\mathbf{g}$ & - & d & g & - & - & $\mathrm{d}$ & d \\
\hline Tryptophan & g & $\mathrm{g}$ & $\mathbf{g}$ & $\mathrm{g}$ & g & - & - & - \\
\hline Tyrosine & - & g & - & - & - & - & d & $d$ \\
\hline Valine & - & - & - & - & - & - & - & - \\
\hline
\end{tabular}

g, growth when amino acid omitted; d, growth delayed (more than $18 \mathrm{~h}$ ); -, no growth when amino acid omitted. (All amino acids except glycine were L-isomers). 
Table III. Carbohydrate needs for growth by CNS

\begin{tabular}{|c|c|c|c|c|c|c|c|c|}
\hline \multirow{3}{*}{$\begin{array}{l}\text { Carbohydrate source* } \\
\text { in the medium of } \\
\text { Gladstone }\end{array}$} & \multicolumn{8}{|c|}{ Growth of strains } \\
\hline & \multicolumn{4}{|c|}{ slime non-producers } & \multicolumn{4}{|c|}{ slime producers } \\
\hline & A2057 & C988 & $\mathrm{C} 362$ & $\mathrm{C} 1276$ & C1543 & C762 & RP-12 & RP-62A \\
\hline None & - & - & - & - & - & - & - & - \\
\hline Glucose & g & $\mathbf{g}$ & g & g & g & g & g & $\mathbf{g}$ \\
\hline Galactose & d & $\mathrm{g}$ & $\mathrm{d}$ & - & - & g & $\mathbf{g}$ & g \\
\hline Mannose & d & $\mathbf{g}$ & d & - & - & - & $\mathrm{g}$ & $\mathbf{g}$ \\
\hline Fructose & d & g & d & d & g & g & $\mathrm{g}$ & $\mathrm{g}$ \\
\hline Sucrose & g & g & d & d & g & $g$ & $g$ & g \\
\hline Lactose & $\mathrm{d}$ & $\mathbf{g}$ & d & g & $\mathrm{d}$ & g & g & g \\
\hline Maltose & d & $\mathrm{g}$ & - & g & - & g & $\mathbf{g}$ & $\mathbf{g}$ \\
\hline
\end{tabular}

-, No growth; g, growth; d, growth delayed.

* All at $1 \% \mathrm{w} / \mathrm{v}$ in medium.

carbohydrate source acceptable to all the strains tested, and in its presence growth was maximal.

\section{Requirements for slime production}

Slime-producing strains (RP-12, RP-62A, C1543 and $\mathrm{C762}$ ) were inoculated into medium $\mathbf{A}$ after addition of various supplements at differing concentrations and in various combinations. The results obtained are summarised in table IV. Vitamins and an organic nitrogen source were always required for growth. Adding yeast extract promoted slime production; supplementing with Casamino acids alone allowed growth but the addition of trace elements, or adenine and guanine, or sodium acetate, was required for slime production. Replacing yeast.extract or Casamino acids by a defined amino-acid mixture formulated in relation to the previous growth-promotion experiments (table II) allowed excellent slime elaboration by all four test strains, as long as either trace elements or adenine and guanine were present.

Table IV. Slime production by CNS in supplemented medium A

\begin{tabular}{|c|c|c|c|c|}
\hline \multirow{2}{*}{$\begin{array}{l}\text { Supplements to } \\
\text { medium } A+\text { vitamins }\end{array}$} & \multicolumn{4}{|c|}{$\begin{array}{c}\text { Growth, and slime production, of } \\
\text { strains }\end{array}$} \\
\hline & RP-12 & RP-62A & C1543 & C762 \\
\hline $\begin{array}{l}\mathrm{Nil} \\
\mathrm{Na} \text { acetate } \cdot 3 \mathrm{H}_{2} \mathrm{O} \\
\text { Trace elements } \\
\text { CA } 3 \% \\
\text { YE } 0 \cdot 1 \% \\
\text { CA } 3 \%+\text { trace elements } \\
\text { CA } 3 \%+\text { adenine/guanine } \\
\text { CA } 3 \%+\text { uracil } \\
\text { CA } 3 \%+\mathrm{Na} \text { acetate } \cdot 3 \mathrm{H}_{2} \mathrm{O} \\
\text { DAAM } \\
\text { DAAM + trace elements } \\
\text { DAAM + adenine/guanine } \\
\text { DAAM + Na acetate } \cdot 3 \mathrm{H}_{2} \mathrm{O}\end{array}$ & $\begin{array}{l}- \\
- \\
- \\
\mathbf{g} \\
\mathbf{S} \\
\mathbf{S} \\
\mathbf{S} \\
\mathbf{g} \\
\mathbf{S} \\
\mathbf{g} \\
\mathbf{S} \\
\mathbf{S} \\
\mathbf{S}\end{array}$ & $\begin{array}{l}- \\
- \\
- \\
\mathbf{g} \\
\mathbf{S} \\
\mathbf{S} \\
\mathbf{S} \\
\mathbf{g} \\
\mathbf{S} \\
\mathbf{g} \\
\mathbf{S} \\
\mathbf{S} \\
\mathbf{g}\end{array}$ & $\begin{array}{l}- \\
- \\
- \\
\mathbf{g} \\
\mathbf{S} \\
\mathbf{S} \\
\mathbf{S} \\
\mathbf{g} \\
\mathbf{S} \\
\mathbf{g} \\
\mathbf{S} \\
\mathbf{S} \\
\mathbf{g}\end{array}$ & $\begin{array}{l}- \\
- \\
- \\
\mathbf{g} \\
\mathbf{S} \\
\mathbf{S} \\
\mathbf{S} \\
\mathbf{g} \\
\mathbf{S} \\
\mathbf{g} \\
\mathbf{S} \\
\mathbf{S} \\
\mathbf{g}\end{array}$ \\
\hline
\end{tabular}

-, No growth; g, growth; $S$, growth + slime production (assay by tube method). CA, Casamino acids (Difco); YE, yeast extract (Oxoid); DAAM, defined amino-acid mixture.
This formulation is medium HHW and is shown in detail in table I.

Medium HHW and tryptic soy broth (a medium used widely by other workers) were compared for their ability to facilitate slime production by CNS. Using the tube method, it was hard to detect differences between the two media with good slime producers (strains RP-62A and RP-12) but the two weak slime producers (strains $\mathrm{C} 1543$ and $\mathrm{C} 762$ ) produced slime more readily in medium HHW (table V).

When measured spectrophotometrically, slime production was better in medium HHW (table VI). Similar results were obtained when the adherent biomass was measured by ATP bioluminescence (table VII).

Table V. Assay of slime production by tube test

\begin{tabular}{lcc}
\hline \multirow{2}{*}{ Strain no } & \multicolumn{2}{c}{ Slime production in } \\
\cline { 2 - 3 } & medium HHW & tryptic soy broth \\
\hline R62A & +++ & +++ \\
RP-12 & ++ & ++ \\
C762 & ++ & + \\
C1453 & ++ & + \\
C362 & - & - \\
C988 & - & - \\
\hline
\end{tabular}

,- No slime, +-+++ , increasing intensity of colour and thickness of stained adherent biomass, as judged by two observers.

Table VI. Assay of slime by spectrophotometric method

\begin{tabular}{l|cc}
\hline & \multicolumn{2}{|c}{ Mean $\left(\right.$ SD) OD $_{490}$ after growth in } \\
\cline { 2 - 3 } Strain no. & medium HHW & tryptic soy broth \\
& & \\
\hline RP-62A & $1.79(0 \cdot 19)$ & $1.09(0 \cdot 11)$ \\
RP-12 & $0.41(0 \cdot 13)$ & $0.23(0.09)$ \\
C762 & $0.30(0.07)$ & $0.12(0 \cdot 10)$ \\
C1543 & $0.34(0 \cdot 10)$ & $0.14(0.08)$ \\
C362 & $0.05(0.01)$ & $0.06(0.02)$ \\
C988 & $0.05(0.01)$ & $0.05(0.01)$ \\
\hline
\end{tabular}

* Mean of results of nine tests. 
Table VII. Assay of slime by measurement of ATP bioluminescence

\begin{tabular}{|c|c|c|}
\hline \multirow{2}{*}{ Strain no. } & \multicolumn{2}{|c|}{$\begin{array}{c}\text { Mean }{ }^{*}(\mathrm{SD}) \text { picomoles of ATP } \\
\text { after growth in }\end{array}$} \\
\hline & medium HHW & tryptic soy broth \\
\hline $\begin{array}{l}\text { RP-62A } \\
\text { RP-12 } \\
\text { C762 } \\
\text { C1543 } \\
\text { C362 } \\
\text { C988 }\end{array}$ & $\begin{array}{l}68.65(4 \cdot 27) \\
50.4 \quad(4 \cdot 12) \\
32.3 \quad(6 \cdot 2) \\
37 \cdot 1 \quad(5 \cdot 8) \\
17.91(1 \cdot 19) \\
19.88(2 \cdot 5)\end{array}$ & $\begin{array}{l}51 \cdot 12(3.90) \\
31.89(3.1) \\
19.4(4.9) \\
21.6 \quad(4.6) \\
17 \cdot 1 \quad(1.10) \\
7.19(6.63)\end{array}$ \\
\hline
\end{tabular}

* Mean of results of nine tests.

\section{Discussion}

There are a few reports of the chemical nature of slime produced by staphylococci and, in almost all studies, complex media were used to prepare it. ${ }^{7-10}$

\section{References}

1. Bayston R, Penny SR. Excessive production of mucoid substance in Staphylococcus SIIA: a possible factor in colonisation of Holter shunts. Dev Med Child Neurol 1972; 14 Suppl $27: 25-28$.

2. Christensen GD, Bisno AL, Parisi JT, McLaughlin B, Hester MG, Luther RW. Nosocomial septicemia due to multiple antibiotic-resistant Staphylococcus epidermidis. Ann Intern Med 1982; 96: 1-10.

3. Christensen GD, Simpson WA, Bisno AL, Beachey EH. Adherence of slime producing strains of Staphylococcus epidermidis to smooth surfaces. Infect Immun 1982; 37: 318-326.

4. Christensen GD, Simpson WA, Bisno AL, Beachey EH. Experimental foreign body infections in mice challenged with slime producing Staphylococcus epidermidis. Infect Immun 1983; 40: 407-410.

5. Davenport DS, Massanari RM, Pfaller MA, Bale MJ, Hierholzer WJ. Usefulness of a test for slime production as a marker for clinically significant infections with coagulasenegative staphylococci. $J$ Infect Dis 1986; 153: 332-339.

6. Peters G, Schumacher-Perdreau F, Jansen B, Bey M, Pulverer G. Biology of Staphylococcus epidermidis extracellular slime. Zentralbl Bakteriol Mikrobiol Hyg 1987; 16 Suppl: 15-32.

7. Ekstedt RD, Bernhard JM. Preparation and characterization
The use of complex media to isolate slime present in the culture fluid is disadvantageous because high molecular weight ingredients from the medium are likely to be present. Peters et $a l^{6}{ }^{6}$ used a chemically defined medium but the effects and requirements of different components on growth and slime production were not recorded. The newly developed simpler chemically defined medium described here (HHW) contains components essential for growth or slime production only and, when tested with several strains and methods, appears to be at least as good as tryptic soy broth for supporting growth and slime production.

The exact chemical nature of slime is not known ${ }^{6}$ and there is no specific marker for its detection. Medium HHW is now being used to collect slime material from CNS for analysis.

This work was supported by a scholarship from the Government of Pakistan to M.H.

of slime layer material produced by Staphylococcus aureus. Proc Soc Exp Biol Med 1973; 142: 86-91.

8. Seltmann G, Beer W. Chemische Zusammensetzung des Kapselmaterials von Staphylococcus aureus Stamm 1193/ 74. Z Allg Mikrobiologie 1976; 16: 445-452.

9. Ludwicka A, Ulenbruck G, Peters G et al. Investigation on extracellular slime substance produced by Staphylococcus epidermidis. Zentralbl Bakteriol Mikrobiol Hyg 1984; 258 : 256-267.

10. Tojo M, Yamashita N, Goldmann DA, Pier GB. Isolation and characterization of a polysaccharide adhesin from Staphylococcus epidermidis. J Infect Dis 1988; 157: 713-722.

11. Van De Rijin I, Kessler RE. Growth characteristics of group A streptococci in a new chemically defined medium. Infect Immun 1980; $27: 444-448$.

12. Gladstone GP. The nutrition of Staphylococcus aureus; nitrogen requirements. Brit J Exp Pathol 1937; 18 : 322-327.

13. White PJ. The nutrition of Bacillus megaterium and Bacillus cereus. J Gen Microbiol 1972; 71 : 505-514.

14. Christensen GD, Simpson WA, Younger JJ et al. Adherence of coagulase-negative staphylococci to plastic tissue culture plates: a quantitative model for the adherence of staphylococci to medical devices. J Clin Microbiol 1985; 22: 9961006.

15. White PJ, Woods DD. Biochemical properties of staphylococci sensitive and resistant to sulphonamides. J Gen Microbiol $1965 ; 40$ : $255-271$. 
